\title{
An intimate relationship between thyroid hormone and skin: regulation of gene expression
}

\author{
Dario Antonini ${ }^{1}$, Annarita Sibilio ${ }^{2}$, Monica Dentice ${ }^{2}$ and Caterina Missero ${ }^{1,3}$ * \\ ${ }^{1}$ CEINGE Biotecnologie Avanzate, Napoli, Italy \\ ${ }^{2}$ Department of Clinical Medicine Surgery, University of Naples Federico II, Napoli, Italy \\ ${ }^{3}$ Fondazione IRCCS SDN, Napoli, Italy
}

Edited by:

Warner Simonides, VU University

Medical Center, Netherlands

\section{Reviewed by:}

José C. Moreno, Institute for Medical and Molecular Genetics, Spain

Tania M. Ortiga-Carvalho,

Universidade Federal do Rio de Janeiro, Brazil

${ }^{*}$ Correspondence:

Caterina Missero, CEINGE

Biotecnologie Avanzate, via Gaetano

Salvatore 486, Napoli 80145, Italy

e-mail:missero@ceinge.unina.it
Skin is the largest organ of the human body and plays a key role in protecting the individual from external insults. The barrier function of the skin is performed primarily by the epidermis, a self-renewing stratified squamous epithelium composed of cells that undergo a well-characterized and finely tuned process of terminal differentiation. By binding to their receptors thyroid hormones $(\mathrm{TH})$ regulate epidermal cell proliferation, differentiation, and homeostasis. Thyroid dysfunction has multiple classical manifestations at skin level. Several TH-responsive genes, as well as genes critical for TH metabolism and action, are expressed at epidermal level. The role of TH in skin is still controversial, although it is generally recognized that TH signaling is central for skin physiology and homeostasis. Here we review the data on the epidermis and its function in relation to TH metabolism and regulation of gene expression. An understanding of the cellular and molecular basis of TH action in epidermal cells may lead to the identification of putative therapeutical targets for treatment of skin disorders.

Keywords: thyroid hormones, skin, deiodinase, regulation of gene expression, epidermal development

\section{INTRODUCTION}

Skin plays a key role in protecting the body from dehydration, mechanical trauma, and microbial insults (Figure 1). The epidermis is composed of keratinocytes, and to a lesser extent of resident dendritic cells, $\mathrm{T}$ lymphocytes, melanocytes, and the neuroepithelial sensory Merkel cells. Dendritic cells and T lymphocytes protect skin from microbial insults, which makes skin an active immune organ [reviewed in (1)]. The epidermis receives nutrients from blood vessels in the underlying dermis, which contains several types of cells, including fibroblasts that produce proteoglycans, collagen, and elastic fibers, as well as resident dendritic cells, macrophages, mast cells, and lymphocytes. Hair follicles (HF) and sebaceous glands, two epidermal appendages, are embedded in the dermis and are separated from the dermis by the basement membrane, whose components are secreted by epidermal keratinocytes and dermal fibroblasts.

Being the largest organ of the human body, skin is also an important peripheral neuro-endocrine-immune organ that is closely related to endocrine systems, thus contributing to the maintenance of peripheral hormonal homeostasis. Specialized cells in the skin produce and respond to multiple neurotransmitters, neuropeptides, and hormones thereby making skin a central player in endocrine homeostasis.

This review focuses on the gene expression programs activated in the skin, and in particular in the interfollicular epidermis, during embryogenesis and in adult life in relationship with a specific class of hormones secreted by the thyroid gland, namely the triiodothyronine (T3) and thyroxine (T4).

\section{TRANSCRIPTIONAL CONTROL OF EPIDERMAL DEVELOPMENT AND ESTABLISHMENT OF BARRIER FUNCTION}

The barrier function of the epidermis is established during embryogenesis and is the result of a complex and coordinated stratification program. During mouse embryogenesis, cells of the surface neuroectoderm are committed to an epidermal fate at embryonic day 8.5 (E8.5), and progressively acquire expression of basal cell markers. Their commitment is regulated in large part by cross-regulation between WNT and BMP signaling. WNT signaling suppresses epidermal cell fate in favor of the neural fate in the dorsal region of the developing embryo, whereas BMP signaling is predominant in the ventral region of the embryo and it is thought to act as epidermal inducer (2). Given the crucial role of BMP signaling in skin development, it is interesting to note that both epidermal cells and dermal fibroblasts express several BMP ligands and BMP receptors. Treatment of these cell types with BMP induces cell-type-specific changes in gene expression programs, which are likely to contribute to the complex effects of BMPs in the developing skin and in skin homeostasis (3).

The first ectodermal-specific marker expressed as early as E8.5 is the transcription factor p63 is a master regulator of stratified epithelia (4-8) that continues to be expressed during embryonic skin development and in the basal proliferative layer in postnatal life also through a positive autoregulatory loop (4). Studies with zebrafish demonstrated that $\mathrm{p} 63$ is a direct target of BMP signaling and blocks neural specification (9). A similar role in maintaining epidermal cell fate has been demonstrated in mammalian cells, where p63 depletion results in ectopic expression of neural and 


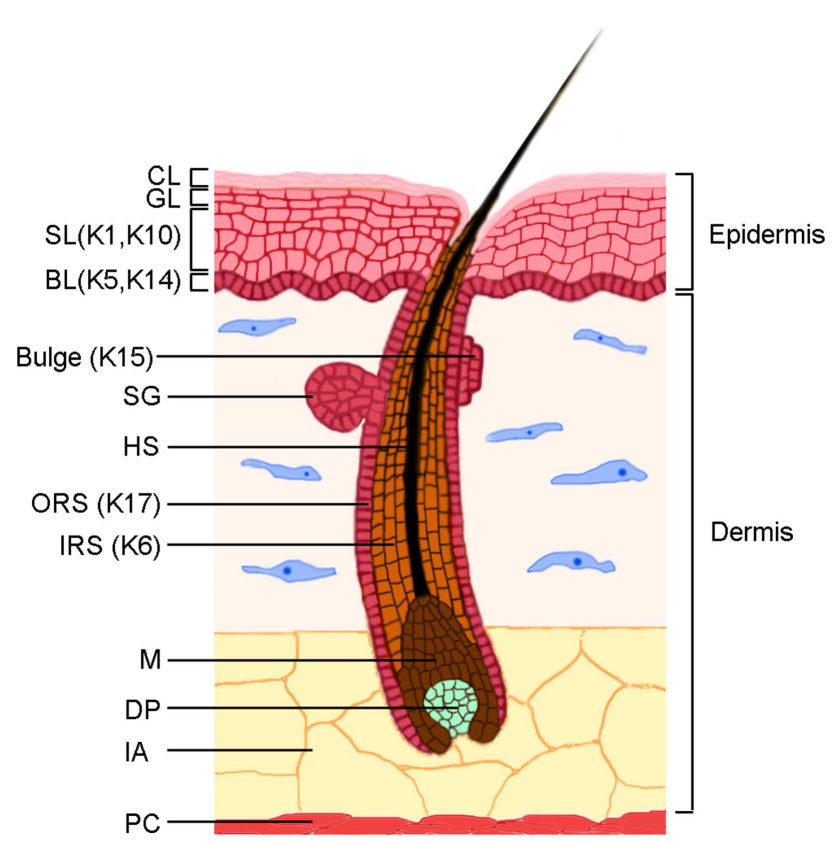

FIGURE 1 |The skin structure. The skin is characterized by two main components, the epidermis and the dermis, which are separated by a basement membrane. The epidermis is constituted by an undifferentiated basal layer (BL) of cells that progressively differentiate in the spinous layer (SL), granular layer (GL), and the cornified layer (CL). The HF consists of an outer root sheath (ORS), an inner root sheath (IRS), and a hair shaft (HS). The epidermal stem cell compartment resides in the BL of the epidermis and in a specific region of the ORS named bulge. The lower part of the follicle, the hair bulb, is characterized by proliferating matrix cells (M) and by the dermal papilla (DP), which is the dermal component of the HF. The sebaceous glands (SG) are integral part of the pilosebaceous unit. The major keratins expressed in different compartments are indicated. The dermis is composed by dense connective tissues in which the fibroblasts are the main components. Intradermal adipocytes (IA) are abundant in the lower part of the dermis, above the panniculus carnosus (PC), a layer of striated muscle cells.

mesenchymal genes (10-12). Interestingly, p63 positively regulates BMP signaling through direct activation of BMP7 and repression of SMAD7 (11-13).

During epidermal morphogenesis, p63 expression is followed by regional expression of keratins K5 and K14 at E9.5 (14). Their expression is regulated directly by p63 itself $(15,16)$, and by other crucial regulators expressed in the early surface ectoderm including transcription factors of the AP-2 family $(14,17,18)$.

Among its multiple functions, p63 plays a crucial role in sustaining epidermal progenitor expansion by directly induction of the fibroblast growth factor receptors Fgrf2 and Fgfr3 (19), and by suppression of the cell cycle inhibitors p21 (Cdkn1a), INK4a (Cdkn2a), ARF (Cdkn2d), and the microRNA miR-34a (20-25). During development, a rapid increase in embryo size is accompanied by frequent symmetric divisions of epidermal progenitors thereby increasing surface area. Stratification occurs through asymmetric cell division starting from E13.5, when the spinous layer of initially proliferating cells expressing keratins K1 and K10 is formed above the basal layer. Loss of this proliferative capacity is associated with maturation into spinous cells, which subsequently undergo further maturation into granular and cornified cells, and by E17.5 the epidermal barrier is fully formed and the skin becomes impermeable. Notch signaling is required for induction of the spinous layer markers, keratins $\mathrm{K} 1$ and $\mathrm{K} 10$, and involucrin (26-28). Cross-talk between the p63 and Notch signaling pathways has been associated to the commitment of keratinocytes to undergo terminal differentiation, because p63 represses a subset of Notch functions, whereas Notch signaling suppresses p63 expression (22). Interestingly, p63 depletion inhibits expression of Notch1 itself and its ligand Jag1 $(13,29)$. Therefore, during normal development, Notch is necessary and sufficient to induce many aspects of differentiation, and the cross-talk between p63 and Notch signaling is essential to control stratification during development.

Also Irf6, Ikk $\alpha$, and Klf4 are crucial regulators of epidermal development and keratinocyte differentiation. Ikk $\alpha$, a p63 target gene $(30,31)$, is required to exit from the basal cell compartment, although its function in the switch between basal and suprabasal cell fate is not cell-autonomous (32-35). Irf6-deficient mice have a hyperproliferative epidermis that results in the expansion of the basal and spinous layer, loss of granular layer, and defective epidermal barrier $(36,37)$. Interestingly, Irf6 is induced during differentiation via p63- and Notch-dependent mechanisms (38-40), whereas Irf6 negatively regulates p63 levels by inducing proteasome-mediated degradation (40). Granular layer and epidermal barrier formation is also controlled by the transcription factor Klf4 as revealed by studies in mice lacking or overexpressing $\operatorname{Klf} 4(41,42)$. Thus, these transcription factors orchestrate the differentiation program during development although their interconnections have not been fully established.

\section{STRUCTURE OF MATURE EPIDERMIS}

In adult epidermis, keratinocytes undergo a continuous program of terminal differentiation, starting from the basal layer and moving outward to form the suprabasal layers. Epidermal cells are protected from physical trauma by specialized intermediate filaments (IF) and specific cell-basement membrane and cell-cell junctions. In epidermal keratinocytes, IF are mainly constituted by keratins and are particularly abundant; in fact, they account for up to $85 \%$ of the total protein content of the cells. Keratin mutations or depletions cause cells to become fragile and prone to ruptures [reviewed in (43)]. Keratins K5 and K14 are expressed in the basal layer of the interfollicular epidermis and of the HF, as well as in the basal layer of other stratified epithelia. K15 is a less abundant component of the basal IF, and is thought to compensate at least in part for loss of K14 by assembling with K5 (44). Although the function of K15 in the skin has not been fully elucidated, it is an intriguing molecule since it is more abundant in the newborn interfollicular epidermis and in the adult HF bulge (45) where in cells with higher proliferative potential and stem cell like properties. Under physiological conditions, K5/K14 are substituted by $\mathrm{K} 1 / \mathrm{K} 10$ in the spinous layer, whereas under hyperproliferative conditions, including inflammation, acute injury, psoriasis, and carcinoma, the HF keratins $\mathrm{K} 6, \mathrm{~K} 16$, and $\mathrm{K} 17$ are induced suprabasally in the epidermis [(46) and reference therein]. Beside its role in the IF, K17 regulates cell growth and size by inducing 
protein synthesis through the Akt/mTOR-dependent pathway (47). In a more indirect fashion, K17 expression in the epidermis is also involved in inflammation-dependent cell proliferation by inducing an immune response (48).

Basal keratinocytes are anchored to the basement membrane by integrins and by specialized junctions, hemidesmosomes constituted by integrins, and other proteins that connect them to the actin cytoskeleton [reviewed in (49)]. Epidermal cells are tightly packed one to the other by cell-cell junctions, namely desmosomes, adherens junctions, and tight junctions [reviewed in (50)]. Adherens junctions are intercellular structures that couple intercellular adhesion to the actin cytoskeleton and are formed by two cell adhesion receptor complexes, the classical cadherin/catenin complex and the nectin/afadin complex, both of which can link to the actin cytoskeleton.

Desmosomes form a robust network among adjacent cells conferring strength and resiliency to the epidermis, with basal and suprabasal cells expressing different sets of specific desmosomal proteins [reviewed in (51)]. Desmosomal cadherins are transmembrane proteins that form stable associations with desmosomal cadherins in adjacent cells and are linked inside the cell to the keratin cytoskeleton. Interestingly, several components of hemidesmosomes and desmosomes are under the tight transcriptional control of p63 (29, 52-55). By controlling several adhesion molecules, p63 is essential for cell adhesion in stratified epithelia and its absence leads to epidermal fragility $(29,53)$.

The final step in epidermal differentiation involves the formation of the epidermal barrier, which is characterized by the formation of cornified cell envelopes constituted by proteins crosslinked by specific enzymes into a rigid scaffold and by lipids covalently attached to the exterior surface. The barrier function of the epidermis is also maintained by tight junctions, and the first functional evidence that epidermal barrier function requires a tight junction component came from claudin-1-deficient mice, which die of massive transepidermal water loss due to impaired barrier function of the granular layer (56).

\section{THYROID HORMONE ACTION AND METABOLISM}

The thyroid hormone (TH) is a key element in the endocrine control of epidermal development and function [reviewed in (57)]. Clinical evidence (58-63) as well as studies conducted in hypothyroid mice and rats (64-66) suggest that TH is involved in epidermal proliferation and differentiation, hair growth, and wound healing besides affecting the function of dermal fibroblasts. The importance of TH in skin was first shown in lower vertebrates. In Amphibian metamorphosis, the skin is transformed from a bilayered non-keratinized epithelium into a stratified, keratinized epidermis (67).

To exert its functions, TH must overcome several checkpoints, namely TH transporters, TH-metabolizing enzymes (deiodinases), TH receptors (TRs), and their interactions with corepressors and co-activators [reviewed in (68)]. In the bloodstream, the steady-state level of $\mathrm{TH}$ concentration is regulated by the hypothalamic-pituitary-thyroid (HPT) axis. Hypothalamic thyroid releasing-hormone (TRH) stimulates thyrotrophic cells in the anterior pituitary to produce thyroid stimulating-hormone (TSH). In turn, TSH induces the production of pro-hormone thyroxine (T4) and - to a lesser extent - the active form triiodothyronine (T3) by the thyroid gland. Unexpectedly the expression of fully functional proteins typical of the HPT axis, and in particularly of the TSH receptor, the TRH and the THR receptor has been found in human skin and in the HF (58, 69-72). Both, TRH and TSH exert several regulatory effects on skin-specific gene expression and various elements of the HPT axis are transcribed by human skin cell populations $(69,73)$ suggesting that normal human skin might represent a source and extrathyroidal target of $\mathrm{TRH}$ and TSH. Epidermal expression of TSH is up-regulated by $\mathrm{TRH}$ and repressed by THs, demonstrating that intraepidermal TSH expression is regulated by the classical endocrine controls that determine the systemic HPT axis. Moreover, TSH treatment of organ-cultured human skin induces expression epidermal differentiation markers, namely involucrin, loricrin, and keratins 5 and 14 (69). Among other functions, TSH or TRH treatments of scalp human skin ex vivo up-regulate mitochondria biogenesis $(74,75)$. In addition, TSH stimulation up-regulates the transcription of classical TSH target genes thyroglobulin and thyroid transcription factor-1 $(\mathrm{Nkx} 2.1)$ and enhances cAMP production into the culture medium (58), documenting that the TSH receptor expressed by normal human scalp HF in situ is functionally active. Behind the canonical TSH-dependent regulation, recently it has been demonstrated that the TSHR can also be activated by a newly discovered glycoprotein hormone, known as thyrostimulin (76). This hormone is composed of a dimer of unique $\alpha 2$ and $\beta 5$ subunits. Interestingly, both subunits have been documented to be expressed in different tissues including the skin, suggesting a functional role for TSHR signaling via locally produced thyrostimulin in the skin (77). Collectively, these data identify non-classical functions of TRH and TSH-mediated signaling in skin, suggesting that these hormones represent novel players in skin physiology and in human epithelial cell biology and encourage new studies to reveal molecular mechanisms underlying $\mathrm{TH}$ action in skin and its appendages.

Once $\mathrm{TH}$ enters the bloodstream, a low amount of $\mathrm{TH}$, not bound to circulating transport proteins, is free to act on target cells. The initial step in the activation of TH is its transport across the cell membrane that is mediated by different types of TH-transporting proteins (78-80). These transporters are differentially expressed in tissues in a developmental and cell-type-specific fashion and, while most of them accept a variety of ligands, others have elevated substrate specificity $(81,82)$. The latter include monocarboxylate transporters 8 and 10 (MCT8 and MCT10) $(83,84)$, organic anion transporters 2 and 3 (Oatp2 and Oatp3), and L-type amino acid transporters (Lat1 and Lat2). At present, little is known about $\mathrm{TH}$-transporter expression in skin and/or epidermis. The uptake of T3 and T4 is much lower in skin fibroblasts from patients with a MCT8 mutation than in controls, which indicates that MCT8 is expressed in these cells (85).

Within target cells, TH is metabolized by the action of deiodinases, three thioredoxin fold-containing selenoenzymes. These enzymes metabolize $\mathrm{TH}$ in a stage- and tissue-specific manner by a mono-deiodination reaction that involves two distinct pathways. Type I and II deiodinases (D1 and D2) convert the inactive pro-hormone $\mathrm{T} 4$ to the active form $\mathrm{T} 3$ - a process that increases circulating $\mathrm{T} 3$ levels and the availability of the active hormone for 
nuclear receptors [reviewed in (86)]. D1 regulates circulating T3 levels, whereas D2 acts essentially at the intracellular level (87).

In contrast, type III deiodinase (D3) inactivates TH by converting T4 and T3 to the inactive metabolites reverse T3 (rT3) and T2, respectively. All three deiodinases are integral membrane proteins that share a conserved region $\sim 15$ amino acids long within the active center that encodes a selenocysteine that enables the deiodinases to exert enzymatic activity. The subcellular localization differs among the three enzymes, and this affects their systemic versus cellular contributions to $\mathrm{TH}$ homeostasis (88). Notably, the combined actions of D2 and D3 are viewed as a cell-autonomous pre-receptoral mechanism that controls $\mathrm{TH}$ signaling in a time- and tissue-specific manner without affecting serum hormone concentrations $(89,90)$. Often the activities of the D2 and D3 enzymes are finely tuned and oppositely regulated in different cell contexts to ensure the correct balance between the activating/inactivating deiodinases $(91,92)$; Histone $\mathrm{H} 3$ demethylating enzyme (LSD-1) and Foxo3 are critical regulators of this balance in muscle (93), while their role in skin has not been established.

Rat skin was the first organ shown to be an active site for the inner ring mono-deiodination of thyroxine to T3 (94). Subsequently, it was discovered that newborn and adult human epidermal keratinocytes in culture are able to convert T4 to T3 by D2 $(94,95)$, which suggests that a finely regulated $\mathrm{TH}$ metabolism is present at skin level. In addition, various studies showed that D3 protein is present in both mouse and human skin. D3 is abundant in murine epidermis and its expression is finely regulated during murine cutaneous development $(96,97)$. D3 expression first appears in the mouse epidermis at E13.5 just before stratification, and it is highly expressed in the epidermal layers and in the HF at E17.5 and at P0. Moreover, D3 expression is elevated in the growing phase of the HF cycle in the most external portion of the follicle, while it is less detectable in the regressing and resting phases of the HF cycle (96). This is in agreement with the sustained expression of D3 observed in various cancers, including basal cell carcinoma (BCC) and colon cancers, in which D3 is required to facilitate the proliferation of neoplastic cells $(9,90,96)$. D2 and D3 transcripts are expressed also in whole human skin biopsies, and in epidermal and dermal cells, although it remains to be established how these genes are transcriptionally regulated in these cells $(63,72)$. These findings strongly suggest that the D2 and D3 deiodinases are crucial components in the control of intracellular TH in skin, whereas D1 is not expressed in skin (Figure 2).

Once the active hormone T3 is present inside the cells, it can enter the nucleus and reach the TRs, a family of ligand-dependent transcription factors that enhance or inhibit the expression of target genes by binding to specific DNA sequences, known as TH response elements (TREs). Thyroid hormone receptors exist in two isoforms, TR $\alpha$ and $\operatorname{TR} \beta$, which are encoded by the THRA and THRB genes, respectively [reviewed in $(68,98)]$. Also TR expression is specifically modulated and both isoforms express several splicing products that are differently expressed in development and in adult tissues (99) (Figure 2). The TR-TH complex occurs often as a homodimer but also as a heterodimer with the retinoid-X receptor (RXR) (100-102). The ligand availability and concentration of the TR complex in the nucleus ultimately define the level of TR transcription activity. In the classical model of transcriptional regulation by $\mathrm{TH}$, nuclear receptor co-repressors (e.g., NCoR-SMRT) are bound to the TR complex in the unliganded state $(68,98)$. The binding of T3 to TR induces structural changes, and the co-repressors are released and replaced by co-activators (e.g., SRC/p160 or TRAP/DRIP complex) that modify chromatin structures. This complex ultimately recruits RNA polymerase II and leads to transcriptional activation of responsive genes (68). According to a debated non-classical mechanism of TH action, T3 and T4 exerts also a non-genomic effect. Specifically, TH signaling results from the binding of $\mathrm{T} 3$ and $\mathrm{T} 4$ to a membrane integrin, $\alpha v \beta 3$, which leads to activation of the PI3K and MAPK transduction pathways and in turn increases target gene transcription [reviewed in (103)].

TH receptors are expressed in skin (104-106) and play a functional role as demonstrated by the phenotype of the double TR $\alpha$ and TR $\beta$ deficient mice (107). Epidermal cell proliferation and cyclin D1 expression is reduced in the interfollicular epidermis of mice lacking both $\operatorname{TR} \alpha$ and $\operatorname{TR} \beta$ under basal conditions and

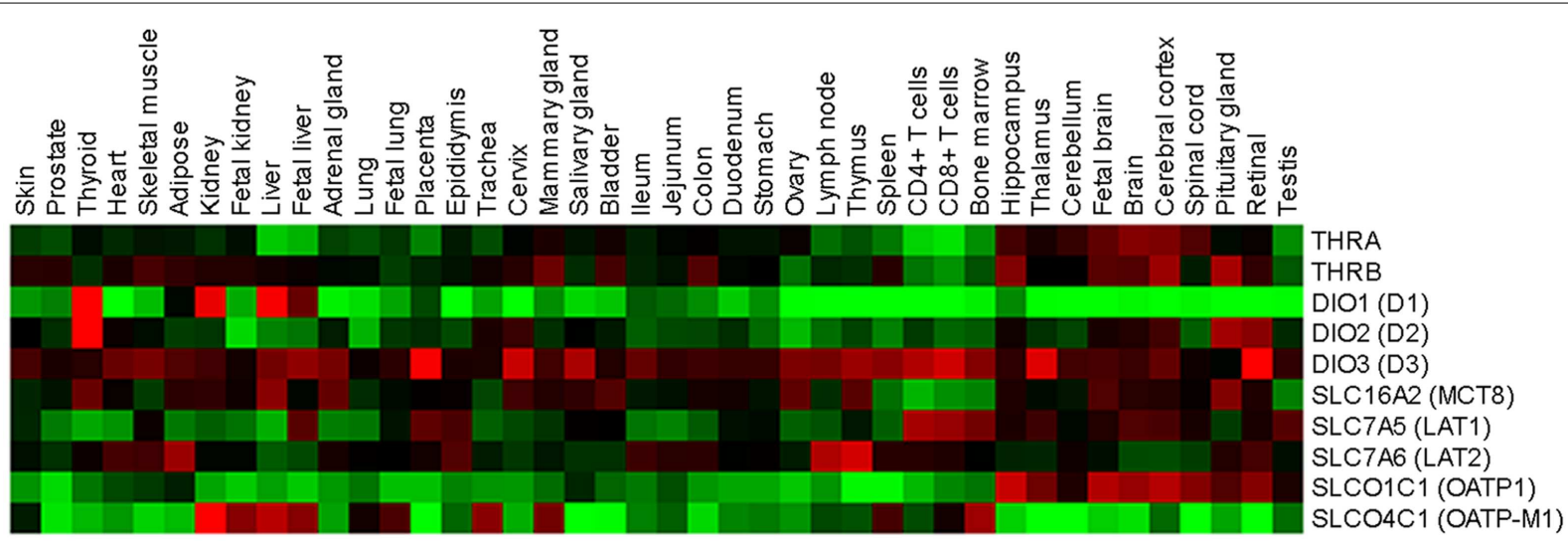

FIGURE 2 | Relative expression profiles of TH regulators and effectors in normal human tissues. Forty-two normal human tissues were analyzed for TH regulators and effectors using a custom high-density microarrays (GEO accession: GSE14938) (126). Results are expressed as heat map of fold changes (log10 ratio) relative to the pool of tissues. 
upon treatment with the phorbol ester TPA or with retinoic acid $(107,108)$. In parallel with reduced epidermal cell proliferation, expression of proinflammatory cytokines coupled with signs of skin inflammation is induced in double $\operatorname{TR} \alpha$ and $\operatorname{TR} \beta$ deficient skin. Further investigation, possibly with conditional mouse models, are required to determine whether reduced cell proliferation in the epidermis is a cell-autonomous phenotype.

\section{REGULATION OF GENE EXPRESSION BY THYROID HORMONE IN THE SKIN UNDER PHYSIOLOGICAL AND PATHOLOGICAL CONDITIONS}

In humans, thyroid dysfunction is associated with alterations in skin architecture and homeostasis [reviewed in (62)]. In hyperthyroid individuals, skin often presents with some of the following symptoms: softness, perspiration, heat, itching, generalized pruritus, chronic urticaria, vitiligo, and diffuse skin pigmentation (109, 110). In addition, the epidermis is usually thinner than normal. In hypothyroid subjects, the skin is dry, cold, and rough. The epidermis is hyperkeratotic, alopecia may develop, and there is diffuse myxedema (110).

The molecular mechanisms at the basis of these cutaneous symptoms have not been clarified, but there is evidence implicating $\mathrm{TH}$ in the molecular control of epidermal differentiation and barrier formation during development $(111,112)$, hair growth, sebum production, keratinocyte proliferation, and keratin gene expression (62,111-113). Indeed, $\mathrm{TH}$ action is crucial for the balance between proliferation and differentiation in normal and pathological conditions, including epidermal regeneration (65) and cutaneous cancer (96).

Many keratins have been identified as TH-responsive genes [reviewed in (61)]. In amphibian metamorphosis, TH is required for skin changes and correlates with the expression of adult keratins and the loss of embryonic keratins (114). In mammalian epidermis and in the HF, TH regulates a number of keratins, including K5, K14, K6, K16, and K17 (63, 64, 113, 115, 116). Similarly, $\operatorname{TR} \alpha$ and $\operatorname{TR} \beta$ can regulate either positively or negatively the expression of selected keratins in cultured cells (61, 117-119). Another TH-responsive keratin is K15; in fact, its promoter activity is significantly induced by the presence of T3 (119), and physiological concentrations of TH induce its expression in epithelial stem cells of adult human scalp HFs (120).

Various studies suggest that $\mathrm{TH}$ is also a key regulator of several ubiquitously expressed genes involved in keratinocyte proliferation and differentiation, although $\mathrm{TH}$ function is skin is still controversial. The TH analog (TRIAC) stimulates epidermal thickening in mice and promotes human keratinocyte proliferation by activating cyclin D1 expression and promoting entry into the $\mathrm{S}$ phase of the cell cycle (121). Hair matrix keratinocytes treated with TRH and T4 show increased proliferation and inhibited apoptosis $(63,71)$. In contrast, Tiede et al. demonstrated that THs reduce proliferation, cyclin D1 expression, and induce apoptosis of isolated K15-positive HF stem cells (120).

An anti-proliferative function of THs in the skin has been shown also in mouse keratinocytes and in BCC, the most frequent

Table 1 | Regulation of gene expression by TH in skin cells.

\begin{tabular}{|c|c|c|c|}
\hline Keratin genes & TH regulation & Cellular system & Reference \\
\hline K5 & $\downarrow$ & Normal human epidermal keratinocytes & $(115)$ \\
\hline K14 & $\downarrow$ & Normal human epidermal keratinocytes, human HFs & $(63,115)$ \\
\hline K6 & $\uparrow$ & Human epidermal keratinocytes (HaCat), human HFs & $(63,64)$ \\
\hline K16 & $\uparrow$ & Human epidermal keratinocytes (HaCat) & $(64)$ \\
\hline K17 & $\downarrow, \uparrow$ & Human epidermal keratinocytes (HaCat) & $(64,115)$ \\
\hline K15 & $\uparrow$ & Human epithelial HF stem cells & $(119,120)$ \\
\hline \multicolumn{4}{|c|}{ Other (TH-responsive) genes } \\
\hline Cyclin D1 & $\uparrow, \downarrow$ & Mouse/human epidermal keratinocytes, human epithelial HF stem cells & $(96,107,120,121)$ \\
\hline P19, p27 & $\uparrow$ & Mouse epidermal keratinocytes & $(107)$ \\
\hline AP1, NF-KB, STAT3 & $\downarrow$ & Mouse epidermal keratinocytes & $(107)$ \\
\hline TGF- $\beta 2$ & $\downarrow$ & Mouse epidermal keratinocytes & $(107)$ \\
\hline AKR & $\uparrow$ & Human skin fibroblasts & $(123)$ \\
\hline RAB3B & $\uparrow$ & Human skin fibroblasts & $(123)$ \\
\hline COLVIA3-COLVIIIA1 & $\uparrow$ & Human skin fibroblasts & $(123)$ \\
\hline ENO1 & $\uparrow$ & Human skin fibroblasts & $(123)$ \\
\hline $\mathrm{HIF}-1 \alpha$ & $\uparrow$ & Human skin fibroblasts & $(123)$ \\
\hline ENO1 & $\uparrow$ & Human skin fibroblasts & $(123)$ \\
\hline ZAKI $4 \alpha$ & $\uparrow$ & Human skin fibroblasts & $(123)$ \\
\hline GLUT-1 & $\uparrow$ & Human skin fibroblasts & $(123)$ \\
\hline FGF7 & $\downarrow$ & Human skin fibroblasts & $(123)$ \\
\hline $\mathrm{ADH} 1 \mathrm{~B}$ & $\downarrow$ & Human skin fibroblasts & $(123)$ \\
\hline HAS2 & $\downarrow$ & Dermal cells & $(124)$ \\
\hline Integrin $\beta 4$ & $\downarrow$ & Human epidermal keratinocytes & $(125)$ \\
\hline Plectin & $\downarrow$ & Human epidermal keratinocytes & $(125)$ \\
\hline COLXVII & $\downarrow$ & Human epidermal keratinocytes & $(125)$ \\
\hline
\end{tabular}


human cancer, which originates from epidermal stem cell compartment in response to aberrant constitutive activation of the Sonic Hedgehog (Shh) pathway (122). Shh, through the transcriptional factor Gli2, directly induces local inactivation of $\mathrm{TH}$ by up-regulation of D3 (the TH action terminator) in proliferating keratinocytes and in mouse and human BCCs, thus resulting in increased cyclin D1 and keratinocyte proliferation. Consistently, D3 knockdown in BCC cells causes a drastic reduction of cellular proliferation and a reduction in the growth of BCC xenografts in nude mice in vivo (96). On the other hand, Hedgehog signaling promotes reduction of the $\mathrm{TH}$ signaling by $\mathrm{D} 2$ degradation (the principal $\mathrm{TH}$ activator) via the E3 ubiquitin ligase adaptor (WSB-1) in embryonic structures during chicken development (96).

Several gene expression profiling studies have identified THresponsive genes in human skin fibroblasts and in dermal cells (Table 1). For instance, members of the aldo-keto reductase (AKR) family, a member of the RAS oncogene family (RAB3B), PFKP, collagen (COLVIA3-COLVIIIA1), solute carrier family 16 member 3 (SLC16A3), enolase 1 (ENO1), the hypoxia-inducible factor (HIF)-1 $\alpha$, a calcineurin inhibitor ZAKI $4 \alpha$ (also known as Down syndrome critical region $1 \mathrm{~L} 1$ ), and glucose transporter 1 (GLUT1) are all increased in human skin fibroblasts treated with T3 (123). In the same condition, TH mediates the down-regulation of fibroblast growth factor 7 (FGF7), a potent

\section{REFERENCES}

1. Nestle FO, Di Meglio P, Qin JZ, Nickoloff BJ. Skin immune sentinels in health and disease. Nat Rev Immunol (2009) 9(10):67991. doi:10.1038/nri2622

2. Stern CD. Neural induction: 10 years on since the 'default model'. Curr Opin Cell Biol (2006) 18(6):692-7. doi:10.1016/j.ceb.2006.09.002

3. Fessing MY, Atoyan R, Shander B, Mardaryev AN, Botchkarev VV Jr, Poterlowicz K, et al. BMP signaling induces cell-type-specific changes in gene expression programs of human keratinocytes and fibroblasts. J Invest Dermatol (2010) 130(2):398-404. doi:10. 1038/jid.2009.259

4. Antonini D, Rossi B, Han R, Minichiello A, Di Palma T, Corrado $\mathrm{M}$, et al. An autoregulatory loop directs the tissue-specific expression of p63 through a longrange evolutionarily conserved enhancer. Mol Cell Biol (2006) 26(8):3308-18. doi:10.1128/MCB. 26.8.3308-3318.2006

5. Mills AA, Zheng B, Wang XJ, Vogel H, Roop DR, Bradley A. p63 is a p53 homologue required for limb and epidermal morphogenesis. Nature (1999) 398(6729):70813. doi:10.1038/19531
6. Yang A, Schweitzer R, Sun D, Kaghad M, Walker N, Bronson RT, et al. p63 is essential for regenerative proliferation in limb, craniofacial and epithelial development. Nature (1999) 398(6729):714-8. doi:10.1038/19539

7. Yang A, Kaghad M, Wang Y, Gillett E, Fleming MD, Dotsch V, et al. p63, a p53 homolog at 3q27-29, encodes multiple products with transactivating, death-inducing, and dominant-negative activities. Mol Cell (1998) 2(3):305-16. doi: 10.1016/S1097-2765(00)80275-0

8. Koster MI, Kim S, Mills AA, DeMayo FJ, Roop DR. p63 is the molecular switch for initiation of an epithelial stratification program. Genes Dev (2004) 18(2):126-31. doi:10.1101/ gad.1165104

9. Bakkers J, Hild M, Kramer C, Furutani-Seiki M, Hammerschmidt M. Zebrafish DeltaNp63 is a direct target of Bmp signaling and encodes a transcriptional repressor blocking neural specification in the ventral ectoderm. Dev Cell (2002) 2(5):617-27. doi: 10.1016/S1534-5807(02)00163-6

10. Barbieri CE, Tang LJ, Brown KA, Pietenpol JA. Loss of p63 leads to increased cell migration and up-regulation of genes involved

stimulator of epidermal proliferation, and alcohol dehydrogenase 1B (ADH1B) (123). In dermal cells, T3 inhibits the synthesis of hyaluronate (HA), which is a type of glycosaminoglycan, by down-regulating HA synthase 2 (HAS2) (124). All these THresponsive genes exert a variety of regulatory functions in development and metabolism. Lastly, a set of genes associated with cell-basement membrane cell adhesion (integrin beta4, plectin, and collagen XVII) is suppressed in T3-treated human epidermal keratinocytes (125).

In conclusion, we provide an overview of recent data about the intricate mechanisms controlling intracellular $\mathrm{TH}$ action in skin and in particular in the epidermal compartment. We focus particularly on the role of TH metabolism and deiodinases in pathophysiological settings. Despite progress in our understanding of the function of these enzymes, much more remains to be discovered. In particular, the tissue-specific deletion of individual, and combined, deiodinases at epidermal level will certainly shed light on their role in the epidermal compartment in normal and pathological conditions. The concept that a finely tuned $\mathrm{TH}$ concentration is essential in the control of proliferation versus differentiation raises the possibility of interfering with such mechanisms for therapeutic purposes. Unraveling these complex interactive mechanisms is an exciting challenge for the future and a promising source of information to determine how to regulate $\mathrm{TH}$ action in skin.

in invasion and metastasis. Cancer Res (2006) 66(15):7589-97. doi:10.1158/0008-5472.CAN-062020

11. Rostagno P, Wolchinsky Z, Vigano AM, Shivtiel S, Zhou H, Van Bokhoven H, et al. Embryonic stem cells as an ectodermal cellular model of human p63-related dysplasia syndromes. Biochem Biophys Res Commun (2010) 395(1):131-5. doi:10.1016/j.bbrc.2010.03.154

12. De Rosa L, Antonini D, Ferone G, Russo MT, Yu PB, Han R, et al. p63 Suppresses non-epidermal lineage markers in a bone morphogenetic protein-dependent manner via repression of Smad7. J Biol Chem (2009) 284(44):30574-82. doi:10.1074/jbc.M109.049619

13. Laurikkala J, Mikkola ML, James M, Tummers M, Mills AA, Thesleff I. p63 regulates multiple signalling pathways required for ectodermal organogenesis and differentiation. Development (2006) 133(8):155363. doi:10.1242/dev.02325

14. Byrne C, Tainsky M, Fuchs E. Programming gene expression in developing epidermis. Development (1994) 120(9):2369-83.

15. Romano RA, Birkaya B, Sinha S. Defining the regulatory elements in the proximal promoter of DeltaNp63 in keratinocytes: potential roles for $\mathrm{Sp} 1 / \mathrm{Sp} 3$, NF$\mathrm{Y}$, and p63. J Invest Dermatol (2006) 126(7):1469-79. doi:10. 1038/sj.jid.5700297

16. Romano RA, Ortt K, Birkaya B, Smalley K, Sinha S. An active role of the DeltaN isoform of p63 in regulating basal keratin genes K5 and K14 and directing epidermal cell fate. PLoS ONE (2009) 4(5):e5623. doi:10.1371/ journal.pone.0005623

17. Guttormsen J, Koster MI, Stevens JR, Roop DR, Williams T, Winger QA. Disruption of epidermal specific gene expression and delayed skin development in AP-2 gamma mutant mice. Dev Biol (2008) 317(1):187-95. doi:10.1016/j.ydbio.2008.02.017

18. Sinha S, Degenstein L, Copenhaver C, Fuchs E. Defining the regulatory factors required for epidermal gene expression. Mol Cell Biol (2000) 20(7):2543-55. doi:10.1128/MCB. 20.7.2543-2555.2000

19. Ferone G, Thomason HA, Antonini D, De Rosa L, Hu B, Gemei M, et al. Mutant p63 causes defective expansion of ectodermal progenitor cells and impaired FGF signalling in AEC syndrome. EMBO $\mathrm{Mol}$ Med (2012) 4(3):192-205. doi:10.1002/emmm.201100199 
20. Antonini D, Russo MT, De Rosa L, Gorrese M, Del Vecchio L, Missero C. Transcriptional repression of miR-34 family contributes to p63-mediated cell cycle progression in epidermal cells. J Invest Dermatol (2010) 130(5):1249-57. doi:10.1038/jid.2009.438

21. Westfall MD, Mays DJ, Sniezek JC, Pietenpol JA. The Delta Np63 alpha phosphoprotein binds the p21 and 14-3-3 sigma promoters in vivo and has transcriptional repressor activity that is reduced by Hay-Wells syndrome-derived mutations. Mol Cell Biol (2003) 23(7):2264-76. doi:10.1128/MCB. 23.7.2264-2276.2003

22. Nguyen BC, Lefort K, Mandinova A, Antonini D, Devgan V, Della Gatta G, et al. Cross-regulation between Notch and p63 in keratinocyte commitment to differentiation. Genes Dev (2006) 20(8):1028-42. doi:10.1101/gad. 1406006

23. LeBoeuf M, Terrell A, Trivedi S, Sinha S, Epstein JA, Olson EN, et al. $\mathrm{Hdacl}$ and Hdac2 act redundantly to control p63 and p53 functions in epidermal progenitor cells. Dev Cell (2010) 19(6):807-18. doi:10. 1016/j.devcel.2010.10.015

24. Truong AB, Kretz M, Ridky TW, Kimmel R, Khavari PA. p63 regulates proliferation and differentiation of developmentally mature keratinocytes. Genes Dev (2006) 20(22):3185-97. doi:10.1101/gad. 1463206

25. Su X, Cho MS, Gi YJ, Ayanga BA, Sherr CJ, Flores ER. Rescue of key features of the p63-null epithelial phenotype by inactivation of Ink4a and Arf. EMBO $J$ (2009) 28(13):1904-15. doi:10. 1038/emboj.2009.151

26. Okuyama R, Nguyen BC, Talora C, Ogawa E, Tommasi di Vignano $\mathrm{A}$, Lioumi $\mathrm{M}$, et al. High commitment of embryonic keratinocytes to terminal differentiation through a Notch1-caspase 3 regulatory mechanism. Dev Cell (2004) 6(4):551-62. doi:10.1016/ S1534-5807(04)00098-X

27. Rangarajan A, Talora C, Okuyama R, Nicolas M, Mammucari C, $\mathrm{Oh} \mathrm{H}$, et al. Notch signaling is a direct determinant of keratinocyte growth arrest and entry into differentiation. $E M B O$ $J$ (2001) 20(13):3427-36. doi:10. 1093/emboj/20.13.3427

28. Blanpain C, Lowry WE, Pasolli HA, Fuchs E. Canonical notch signaling functions as a commitment switch in the epidermal lineage.
Genes Dev (2006) 20(21):3022-35. doi:10.1101/gad.1477606

29. Romano RA, Smalley K, Magraw C, Serna VA, Kurita T, Raghavan S, et al. DeltaNp63 knockout mice reveal its indispensable role as a master regulator of epithelial development and differentiation. Development (2012) 139(4):772-82. doi:10.1242/dev.071191

30. Koster MI, Dai D, Marinari B, Sano Y, Costanzo A, Karin M, et al. p63 induces key target genes required for epidermal morphogenesis. Proc Natl Acad Sci U S A (2007) 104(9):3255-60. doi:10. 1073/pnas.0611376104

31. Candi E, Terrinoni A, Rufini A, Chikh A, Lena AM, Suzuki Y, et al. p63 is upstream of IKK alpha in epidermal development. J Cell Sci (2006) 119(Pt 22):4617-22. doi: 10.1242/jcs.03265

32. Hu Y, Baud V, Delhase M, Zhang $\mathrm{P}$, Deerinck $\mathrm{T}$, Ellisman $\mathrm{M}$, et al. Abnormal morphogenesis but intact IKK activation in mice lacking the IKKalpha subunit of IkappaB kinase. Science (1999) 284(5412):316-20. doi:10. 1126/science.284.5412.316

33. Takeda K, Takeuchi O, Tsujimura T, Itami S, Adachi O, Kawai T, et al. Limb and skin abnormalities in mice lacking IKKalpha. Science (1999) 284(5412):313-6. doi: $10.1126 /$ science. 284.5412 .313

34. Gareus R, Huth M, Breiden B, Nenci A, Rosch N, Haase I, et al. Normal epidermal differentiation but impaired skin-barrier formation upon keratinocyte-restricted IKK1 ablation. Nat Cell Biol (2007) 9(4):461-9. doi:10.1038/ncb1560

35. Li Q, Lu Q, Hwang JY, Buscher $\mathrm{D}$, Lee KF, Izpisua-Belmonte JC, et al. IKK1-deficient mice exhibit abnormal development of skin and skeleton. Genes Dev (1999) 13(10):1322-8. doi:10.1101/gad. 13.10 .1322

36. Richardson RJ, Dixon J, Malhotra S, Hardman MJ, Knowles L, Boot-Handford RP, et al. Irf6 is a key determinant of the keratinocyte proliferationdifferentiation switch. Nat Genet (2006) 38(11):1329-34. doi:10.1038/ng1894

37. Ingraham CR, Kinoshita A, Kondo S, Yang B, Sajan S, Trout KJ, et al. Abnormal skin, limb and craniofacial morphogenesis in mice deficient for interferon regulatory factor 6 (Irf6). Nat Genet (2006) 38(11):1335-40. doi:10. $1038 /$ ng1903
38. Restivo G, Nguyen BC, Dziunycz P, Ristorcelli E, Ryan RJ, Ozuysal OY, et al. IRF6 is a mediator of Notch pro-differentiation and tumour suppressive function in keratinocytes. EMBO J (2011) 30(22):4571-85. doi:10. 1038/emboj.2011.325

39. Thomason HA, Zhou H, Kouwenhoven EN, Dotto GP, Restivo G, Nguyen BC, et al. Cooperation between the transcription factors p63 and IRF6 is essential to prevent cleft palate in mice. J Clin Invest (2010) 120(5):1561-9. doi: 10.1172/JCI40266

40. Moretti F, Marinari B, Lo Iacono N, Botti E, Giunta A, Spallone G, et al. A regulatory feedback loop involving $\mathrm{p} 63$ and IRF6 links the pathogenesis of 2 genetically different human ectodermal dysplasias. J Clin Invest (2010) 120(5):1570-7. doi:10.1172/JCI40267

41. Jaubert J, Cheng J, Segre JA. Ectopic expression of kruppel like factor 4 (Klf4) accelerates formation of the epidermal permeability barrier. Development (2003) 130(12):2767-77. doi:10. 1242/dev.00477

42. Segre JA, Bauer C, Fuchs E. Klf4 is a transcription factor required for establishing the barrier function of the skin. Nat Genet (1999) 22(4):356-60. doi:10.1038/11926

43. Fuchs E, Cleveland DW. A structural scaffolding of intermediate filaments in health and disease. Science (1998) 279(5350):514-9. doi: 10.1126/science.279.5350.514

44. Lloyd C, Yu QC, Cheng J, Turksen $\mathrm{K}$, Degenstein L, Hutton E, et al. The basal keratin network of stratified squamous epithelia: defining K15 function in the absence of K14. J Cell Biol (1995) 129(5):1329-44. doi:10.1083/jcb. 129.5.1329

45. Liu Y, Lyle S, Yang Z, Cotsarelis G. Keratin 15 promoter targets putative epithelial stem cells in the hair follicle bulge. J Invest Dermatol (2003) 121(5):963-8. doi:10.1046/ j.1523-1747.2003.12600.x

46. McGowan KM, Coulombe PA. Onset of keratin 17 expression coincides with the definition of major epithelial lineages during skin development. J Cell Biol (1998) 143(2):469-86. doi:10. 1083/jcb.143.2.469

47. Kim S, Wong P, Coulombe PA. A keratin cytoskeletal protein regulates protein synthesis and epithelial cell growth. Nature (2006) 441(7091):362-5. doi:10. 1038 /nature04659
48. Depianto D, Kerns ML, Dlugosz AA, Coulombe PA. Keratin 17 promotes epithelial proliferation and tumor growth by polarizing the immune response in skin. Nat Genet (2010) 42(10):910-4. doi: 10.1038/ng.665

49. Litjens SH, de Pereda JM, Sonnenberg A. Current insights into the formation and breakdown of hemidesmosomes. Trends Cell Biol (2006) 16(7):376-83. doi:10.1016/ j.tcb.2006.05.004

50. Brandner JM, Haftek M, Niessen CM. Adherens junctions, desmosomes and tight junctions in epidermal barrier function. Open Dermatol J (2010) 4:14-20. doi:10. 2174/1874372201004020014

51. Getsios S, Huen AC, Green KJ. Working out the strength and flexibility of desmosomes. Nat Rev Mol Cell Biol (2004) 5(4):271-81. doi: 10.1038/nrm1356

52. Carroll DK, Carroll JS, Leong CO, Cheng F, Brown M, Mills AA, et al. p63 regulates an adhesion programme and cell survival in epithelial cells. Nat Cell Biol (2006) 8(6):551-61. doi:10.1038/ncb1420

53. Ferone G, Mollo MR, Thomason HA, Antonini D, Zhou H, Ambrosio R, et al. p63 control of desmosome gene expression and adhesion is compromised in AEC syndrome. Hum Mol Genet (2013) 22(3):531-43. doi:10.1093/ hmg/dds 464

54. Ihrie RA, Marques MR, Nguyen BT, Horner JS, Papazoglu C, Bronson RT, et al. Perp is a p63-regulated gene essential for epithelial integrity. Cell (2005) 120(6):843-56. doi:10.1016/j.cell. 2005.01.008

55. Kurata S, Okuyama T, Osada M, Watanabe T, Tomimori Y, Sato $\mathrm{S}$, et al. p51/p63 controls subunit alpha3 of the major epidermis integrin anchoring the stem cells to the niche. J Biol Chem (2004) 279(48):50069-77. doi:10. 1074/jbc.M406322200

56. Furuse $M$, Hata $M$, Furuse $K$, Yoshida Y, Haratake A, Sugitani Y, et al. Claudin-based tight junctions are crucial for the mammalian epidermal barrier: a lesson from claudin-1deficient mice. J Cell Biol (2002) 156(6):1099-111. doi:10.1083/jcb. 200110122

57. Slominski AT, Zmijewski MA, Skobowiat C, Zbytek B, Slominski RM, Steketee JD. Sensing the environment: regulation of local and global homeostasis by the skin's neuroendocrine system. Adv Anat 
Embryol Cell Biol (2012) 212:v, vii, 1-115.

58. Bodo E, Kromminga A, Biro T, Borbiro I, Gaspar E, Zmijewski MA, et al. Human female hair follicles are a direct, nonclassical target for thyroid-stimulating hormone. J Invest Dermatol (2009) 129(5):1126-39. doi:10.1038/jid. 2008.361

59. Messenger AG. Thyroid hormone and hair growth. $\mathrm{Br} J$ Dermatol (2000) 142(4):633-4. doi:10.1046/ j.1365-2133.2000.03521.x

60. Paus R. Exploring the "thyroidskin connection": concepts, questions, and clinical relevance. $J$ Invest Dermatol (2010) 130(1):710. doi:10.1038/jid.2009.359

61. Ramot Y, Paus R, Tiede S, Zlotogorski A. Endocrine controls of keratin expression. Bioessays (2009) 31(4):389-99. doi:10.1002/ bies.200800121

62. Slominski A, Wortsman J. Neuroendocrinology of the skin. Endocr Rev (2000) 21(5):457-87. doi:10.1210/er.21.5.457

63. van Beek N, Bodo E, Kromminga A, Gaspar E, Meyer K, Zmijewski MA, et al. Thyroid hormones directly alter human hair follicle functions: anagen prolongation and stimulation of both hair matrix keratinocyte proliferation and hair pigmentation. $J$ Clin Endocrinol Metab (2008) 93(11):4381-8. doi:10.1210/jc.2008-0283

64. Safer JD, Crawford TM, Holick MF. A role for thyroid hormone in wound healing through keratin gene expression. Endocrinology (2004) 145(5):2357-61. doi: 10.1210/en.2003-1696

65. Safer JD, Crawford TM, Holick MF. Topical thyroid hormone accelerates wound healing in mice. Endocrinology (2005) 146(10):4425-30. doi:10.1210/en.2005-0192

66. Safer JD, Fraser LM, Ray S, Holick MF. Topical triiodothyronine stimulates epidermal proliferation, dermal thickening, and hair growth in mice and rats. Thyroid (2001) 11(8):717-24. doi:10.1089/ 10507250152484547

67. Furlow JD, Neff ES. A developmental switch induced by thyroid hormone: Xenopus laevis metamorphosis. Trends Endocrinol Metab (2006) 17(2):40-7. doi:10.1016/j. tem.2006.01.007

68. Cheng SY, Leonard JL, Davis PJ. Molecular aspects of thyroid hormone actions. Endocr Rev
(2010) 31(2):139-70. doi:10.1210/ er.2009-0007

69. Bodo E, Kany B, Gaspar E, Knuver J, Kromminga A, Ramot Y, et al. Thyroid-stimulating hormone, a novel, locally produced modulator of human epidermal functions, is regulated by thyrotropinreleasing hormone and thyroid hormones. Endocrinology (2010) 151(4):1633-42. doi:10.1210/en. 2009-0306

70. Cianfarani F, Baldini E, Cavalli A, Marchioni E, Lembo L, Teson M, et al. TSH receptor and thyroid-specific gene expression in human skin. J Invest Dermatol (2010) 130(1):93-101. doi: 10.1038/jid.2009.180

71. Gaspar E, Hardenbicker C, Bodo E, Wenzel B, Ramot Y, Funk $\mathrm{W}$, et al. Thyrotropin releasing hormone (TRH): a new player in human hair-growth control. FASEB J (2010) 24(2):393-403. doi:10.1096/fj.08-126417

72. Slominski A, Wortsman J, Kohn L, Ain KB, Venkataraman GM, Pisarchik A, et al. Expression of hypothalamic-pituitary-thyroid axis related genes in the human skin. J Invest Dermatol (2002) 119(6):1449-55. doi:10.1046/j. 1523-1747.2002.19617.x

73. Ramot Y, Zhang G, Biró T, Langbein L, Paus R. Is thyrotropinreleasing hormone a novel neuroendocrine modulator of keratin expression in human skin? $\mathrm{Br} J$ Dermatol (2013) 169(1):146-51. doi:10.1111/bjd.12264

74. Knuever J, Poeggeler B, Gaspar E, Klinger M, HellwigBurgel T, Hardenbicker C, et al. Thyrotropin-releasing hormone controls mitochondrial biology in human epidermis. $J$ Clin Endocrinol Metab (2012) 97(3):978-86. doi:10.1210/jc.2011-1096

75. Poeggeler B, Knuever J, Gaspar E, Biro T, Klinger M, Bodo E, et al. Thyrotropin powers human mitochondria. FASEB J (2010) 24(5):1525-31. doi:10.1096/fj.09147728

76. Nakabayashi K, Matsumi H, Bhalla A, Bae J, Mosselman S, Hsu SY, et al. Thyrostimulin, a heterodimer of two new human glycoprotein hormone subunits, activates the thyroid-stimulating hormone receptor. J Clin Invest (2002) 109(11):1445-52. doi:10. 1172/JCI200214340

77. Okada SL, Ellsworth JL, Durnam DM, Haugen HS, Holloway JL, Kelley ML, et al. A glycoprotein hormone expressed in corticotrophs exhibits unique binding properties on thyroidstimulating hormone receptor. Mol Endocrinol (2006) 20(2):41425. doi:10.1210/me.2005-0270

78. Visser WE, Friesema EC, Jansen J, Visser TJ. Thyroid hormone transport in and out of cells. Trends Endocrinol Metab (2008) 19(2):50-6. doi:10.1016/j.tem.2007.11.003

79. Friesema EC, Docter R, Moerings EP, Stieger B, Hagenbuch $B$, Meier PJ, et al. Identification of thyroid hormone transporters. Biochem Biophys Res Commun (1999) 254(2):497-501. doi: 10.1006/bbrc.1998.9974

80. Abe T, Kakyo M, Sakagami $\mathrm{H}$, Tokui T, Nishio T, Tanemoto M, et al. Molecular characterization and tissue distribution of a new organic anion transporter subtype (oatp3) that transports thyroid hormones and taurocholate and comparison with oatp2. J Biol Chem (1998) 273(35): 22395-401. doi:10.1074/jbc.273. 35.22395

81. Schweizer U, Kohrle J. Function of thyroid hormone transporters in the central nervous system. Biochim Biophys Acto (2013) 1830(7):3965-73. doi:10. 1016/j.bbagen.2012.07.015

82. Visser WE, van Mullem AA Jansen J, Visser TJ. The thyroid hormone transporters MCT8 and MCT10 transport the affinity-label N-bromoacetyl[(125)I]T3 but are not modified by it. Mol Cell Endocrinol (2011) 337(1-2):96-100. doi:10.1016/j.mce.2011.02.003

83. Friesema EC, Docter R, Moerings EP, Verrey F, Krenning EP, Hennemann G, et al. Thyroid hormone transport by the heterodimeric human system L amino acid transporter. Endocrinology (2001) 142(10):4339-48. doi:10.1210/en. 142.10.4339

84. Friesema EC, Jansen J, Jachtenberg JW, Visser WE, Kester $\mathrm{MH}$, Visser TJ. Effective cellular uptake and efflux of thyroid hormone by human monocarboxylate transporter 10. Mol Endocrinol (2008) 22(6):1357-69. doi:10.1210/me.2007-0112

85. Visser WE, Jansen J, Friesema EC, Kester MH, Mancilla E, Lundgren J, et al. Novel pathogenic mechanism suggested by ex vivo analysis of MCT8 (SLC16A2) mutations. Hum Mutat (2009) 30(1):29-38. doi:10.1002/humu.20808
86. Bianco AC, Salvatore D, Gereben B, Berry MJ, Larsen PR. Biochemistry, cellular and molecular biology, and physiological roles of the iodothyronine selenodeiodinases. Endocr Rev (2002) 23(1):38-89. doi:10.1210/er.23.1.38

87. Gereben B, Zavacki AM, Ribich S, Kim BW, Huang SA, Simonides WS, et al. Cellular and molecular basis of deiodinase-regulated thyroid hormone signaling. Endocr Rev (2008) 29(7):898-938. doi:10. 1210/er.2008-0019

88. Bianco AC, Larsen PR. Cellular and structural biology of the deiodinases. Thyroid (2005) 15(8): 777-86. doi:10.1089/thy.2005.15. 777

89. Salvatore D. Deiodinases: keeping the thyroid hormone supply in balance. J Endocrinol (2011) 209(3):259-60. doi:10.1530/JOE11-0058

90. Dentice M, Luongo C, Ambrosio $\mathrm{R}$, Sibilio A, Casillo A, Iaccarino A, et al. beta-Catenin regulates deiodinase levels and thyroid hormone signaling in colon cancer cells. Gastroenterology (2012) 143(4):1037-47. doi: 10.1053/j.gastro.2012.06.042

91. Dentice M, Salvatore D. Deiodinases: the balance of thyroid hormone: local impact of thyroid hormone inactivation. J Endocrinol (2011) 209(3):273-82. doi:10.1530/JOE-11-0002

92. Dentice M, Marsili A, Zavacki A, Larsen PR, Salvatore D. The deiodinases and the control of intracellular thyroid hormone signaling during cellular differentiation. Biochim Biophys Acta (2013) 1830(7):3937-45. doi:10. 1016/j.bbagen.2012.05.007

93. Ambrosio R, Damiano V, Sibilio A, De Stefano MA, Avvedimento VE, Salvatore D, et al. Epigenetic control of type 2 and 3 deiodinases in myogenesis: role of Lysine-specific Demethylase enzyme and FoxO3. Nucleic Acids Res (2013) 41(6):3551-62. doi:10. 1093/nar/gkt065

94. Huang TS, Chopra IJ, Beredo A, Solomon DH, Chua Teco GN. Skin is an active site for the inner ring monodeiodination of thyroxine to 3,3,5'triiodothyronine. Endocrinology (1985) 117(5):2106-13 doi:10.1210/endo-117-5-2106

95. Kaplan MM, Gordon PR, Pan CY, Lee JK, Gilchrest BA. Keratinocytes convert thyroxine to triiodothyronine. Ann N Y Acad Sci 
(1988) 548:56-65. doi:10.1111/j. 1749-6632.1988.tb18792.x

96. Dentice M, Luongo C, Huang $\mathrm{S}$, Ambrosio R, Elefante A, Mirebeau-Prunier D, et al. Sonic hedgehog-induced type 3 deiodinase blocks thyroid hormone action enhancing proliferation of normal and malignant keratinocytes. Proc Natl Acad Sci U $S$ A (2007) 104(36):14466-71. doi:10.1073/pnas.0706754104

97. Huang MP, Rodgers KA, O’Mara R, Mehta M, Abuzahra HS, Tannenbaum $\mathrm{AD}$, et al. The thyroid hormone degrading type 3 deiodinase is the primary deiodinase active in murine epidermis. Thyroid (2011) 21(11):1263-8. doi:10. 1089/thy.2011.0105

98. Yen PM. Physiological and molecular basis of thyroid hormone action. Physiol Rev (2001) 81(3):1097-142.

99. Oetting A, Yen PM. New insights into thyroid hormone action. Best Pract Res Clin Endocrinol Metab (2007) 21(2):193-208. doi: 10.1016/j.beem.2007.04.004

100. Kliewer SA, Umesono K, Mangelsdorf DJ, Evans RM. Retinoid $\mathrm{X}$ receptor interacts with nuclear receptors in retinoic acid, thyroid hormone and vitamin D3 signalling. Nature (1992) 355(6359):446-9. doi:10.1038/355446a0

101. Yu VC, Delsert C, Andersen B, Holloway JM, Devary OV, Naar AM, et al. RXR beta: a coregulator that enhances binding of retinoic acid, thyroid hormone, and vitamin D receptors to their cognate response elements. Cell (1991) 67(6):1251-66. doi:10.1016/00928674(91)90301-E

102. Zhang XK, Hoffmann B, Tran PB, Graupner G, Pfahl M. Retinoid $\mathrm{X}$ receptor is an auxiliary protein for thyroid hormone and retinoic acid receptors. Nature (1992) 355(6359):441-6. doi:10. 1038/355441a0

103. Moeller LC, Broecker-Preuss M. Transcriptional regulation by nonclassical action of thyroid hormone. Thyroid Res (2011) 4(Suppl 1):S6. doi:10.1186/1756-6614-4S1-S6

104. Ahsan MK, Urano Y, Kato S, Oura $\mathrm{H}$, Arase S. Immunohistochemical localization of thyroid hormone nuclear receptors in human hair follicles and in vitro effect of Ltriiodothyronine on cultured cells of hair follicles and skin. $J \mathrm{Med}$ Invest (1998) 44(3-4):179-84.
105. Billoni N, Buan B, Gautier B, Gaillard O, Mahe YF, Bernard BA. Thyroid hormone receptor betal is expressed in the human hair follicle. Br J Dermatol (2000) 142(4):645-52. doi:10.1046/j. 1365-2133.2000.03408.x

106. Torma H, Rollman O, Vahlquist A. Detection of mRNA transcripts for retinoic acid, vitamin D3, and thyroid hormone (c-erb-A) nuclear receptors in human skin using reverse transcription and polymerase chain reaction. Acta Derm Venereol (1993) 73(2):102-7.

107. Contreras-Jurado C, GarciaSerrano L, Gomez-Ferreria M, Costa C, Paramio JM, Aranda A. The thyroid hormone receptors as modulators of skin proliferation and inflammation. J Biol Chem (2011) 286(27):24079-88. doi:10.1074/jbc.M111.218487

108. Garcia-Serrano L, Gomez-Ferreria MA, Contreras-Jurado C, Segrelles C, Paramio JM, Aranda A. The thyroid hormone receptors modulate the skin response to retinoids. PLOS ONE (2011) 6(8):e23825. doi:10.1371/journal. pone. 0023825

109. Leonhardt JM, Heymann WR. Thyroid disease and the skin. Dermatol Clin (2002) 20(3):473-81, vii. doi:10.1016/S0733-8635(02) 00009-8

110. Safer JD. Thyroid hormone action on skin. Dermatoendocrinology (2011) 3(3):211-5.

111. Hanley K, Rassner U, Elias PM, Williams ML, Feingold KR. Epidermal barrier ontogenesis: maturation in serum-free media and acceleration by glucocorticoids and thyroid hormone but not selected growth factors. J Invest Dermatol (1996) 106(3):404-11. doi:10.1111/15231747.ep12343405

112. Komuves LG, Hanley K, Jiang Y, Elias PM, Williams ML, Feingold KR. Ligands and activators of nuclear hormone receptors regulate epidermal differentiation during fetal rat skin development. $J$ Invest Dermatol (1998) 111(3):429-33. doi:10. 1046/j.1523-1747.1998.00296.x

113. Tomic-Canic M, Day D, Samuels $\mathrm{HH}$, Freedberg IM, Blumenberg M. Novel regulation of keratin gene expression by thyroid hormone and retinoid receptors. J Biol Chem (1996) 271(3):1416-23. doi: 10.1074/jbc.271.3.1416

114. Mathisen PM, Miller L. Thyroid hormone induces constitutive keratin gene expression during Xenopus laevis development. Mol Cell Biol (1989) 9(5):1823-31.

115. Jho SH, Vouthounis C, Lee B, Stojadinovic O, Im MJ, Brem $\mathrm{H}$, et al. The book of opposites: the role of the nuclear receptor co-regulators in the suppression of epidermal genes by retinoic acid and thyroid hormone receptors. I Invest Dermatol (2005) 124(5):1034-43. doi:10. 1111/j.0022-202X.2005.23691.x

116. Tomic-Canic M, Sunjevaric I, Freedberg IM, Blumenberg M. Identification of the retinoic acid and thyroid hormone receptorresponsive element in the human K14 keratin gene. J Invest Dermato (1992) 99(6):842-7. doi:10.1111/ 1523-1747.ep 12614806

117. Jho SH, Radoja N, Im MJ, Tomic-Canic M. Negative response elements in keratin genes mediate transcriptional repression and the cross-talk among nuclear receptors. J Biol Chem (2001) 276(49):45914-20. doi:10.1074/jbc.M103144200

118. Radoja N, Diaz DV, Minars TJ, Freedberg IM, Blumenberg M, Tomic-Canic M. Specific organization of the negative response elements for retinoic acid and thyroid hormone receptors in keratin gene family. J Invest Dermatol (1997) 109(4): 566-72. doi:10.1111/1523-1747. ep12337483

119. Radoja N, Stojadinovic O, Waseem A, Tomic-Canic M, Milisavljevic V, Teebor S, et al. Thyroid hormones and gamma interferon specifically increase K15 keratin gene transcription. Mol Cell Biol (2004) 24(8):3168-79. doi:10.1128/MCB. 24.8.3168-3179.2004

120. Tiede S, Bohm K, Meier N, Funk W, Paus R. Endocrine controls of primary adult human stem cell biology: thyroid hormones stimulate keratin 15 expression, apoptosis, and differentiation in human hair follicle epithelial stem cells in situ and in vitro. Eur J Cell Biol (2010) 89(10):769-77. doi:10.1016/j.ejcb. 2010.06.002

121. Zhang B, Zhang A, Zhou X, Webb $\mathrm{P}, \mathrm{He} \mathrm{W}$, Xia X. Thyroid hormone analogue stimulates keratinocyte proliferation but inhibits cell differentiation in epidermis. Int $J$ Immunopathol Pharmacol (2012) 25(4):859-69.

122. Grachtchouk M, Pero J, Yang SH, Ermilov AN, Michael LE, Wang A, et al. Basal cell carcinomas in mice arise from hair follicle stem cells and multiple epithelial progenitor populations. J Clin Invest (2011) 121(5):1768-81. doi: 10.1172/JCI46307

123. Moeller LC, Dumitrescu AM, Refetoff S. Cytosolic action of thyroid hormone leads to induction of hypoxia-inducible factorlalpha and glycolytic genes. $\mathrm{Mol}$ Endocrinol (2005) 19(12):295563. doi:10.1210/me.2004-0542

124. Pouyani T, Sadaka BH, Papp S, Schaffer L. Triiodothyronine (T3) inhibits hyaluronate synthesis in a human dermal equivalent by downregulation of HAS2. In vitro Cell Dev Biol Anim (2013) 49(3):178-88. doi:10.1007/ s11626-013-9583-7

125. Tomic-Canic M, Stojadinovic O, Lee B, Walsh R, Blumenberg M. Nexus between epidermolysis bullosa and transcriptional regulation by thyroid hormone in epidermal keratinocytes. Clin Transl Sci (2008) 1(1):45-9. doi:10.1111/ j.1752-8062.2008.00015.x

126. She X, Rohl CA, Castle JC, Kulkarni AV, Johnson JM, Chen R. Definition, conservation and epigenetics of housekeeping and tissueenriched genes. BMC Genomics (2009) 10:269. doi:10.1186/14712164-10-269

Conflict of Interest Statement: The authors declare that the research was conducted in the absence of any commercial or financial relationships that could be construed as a potential conflict of interest.

Received: 22 May 2013; accepted: 05 August 2013; published online: 22 August 2013.

Citation: Antonini D, Sibilio A, Dentice $M$ and Missero $C$ (2013) An intimate relationship between thyroid hormone and skin: regulation of gene expression. Front. Endocrinol. 4:104. doi: 10.3389/fendo.2013.00104

This article was submitted to Thyroid Endocrinology, a section of the journal Frontiers in Endocrinology.

Copyright () 2013 Antonini, Sibilio, Dentice and Missero. This is an open-access article distributed under the terms of the Creative Commons Attribution License (CC BY). The use, distribution or reproduction in other forums is permitted, provided the original author(s) or licensor are credited and that the original publication in this journal is cited, in accordance with accepted academic practice. No use, distribution or reproduction is permitted which does not comply with these terms. 